\title{
PERBEDAAN MINAT KARIR ANTARA SISWA SEKOLAH MENENGAH PERTAMA (SMP) DENGAN SISWA MADRASAH TSANAWIYAH (MTs)
}

\author{
Mudhar \\ Bimingan dan Konseling - FKIP Universitas PGRI Adibuana Surabaya \\ mudhar.bps@gmail.com
}

\begin{abstract}
ABSTRAK
Penelitian ini bertujuan untuk mengetahui perbedaan minat karir antara siswa SMP dengan siswa MTs. Penelitian ini dilakukan pada siswa SMP Unggulan Bina Insani Surabaya dan MTs Negeri III Surabaya. Alat ukur minat yang digunakan adalah Rothwell Miller Interest Blank (RMIB), yang dapat mengungkap 12 aspek minat karir, yaitu : outdoor, mechanical, compulational, scientific, personal contact, aesthetic, literary, musical, social service, clerical, practical dan medical. Hasil penelitian ada 3 aspek minat karir yang menunjukkan adanya perbedaan yang signifikan antara minat karir siswa SMP dengan minat karir siswa MTs, yaitu aspek scientific, personal contact dan practical. Sedangkan 9 aspek lainnya menunjukkan tidak ada perbedaan minat karir antara siswa SMP dengan siswa MTs. Aspek-aspek minat karir yang tidak berbeda adalah outdoor, mechanical, compulational, aesthetic, literary, musical, social service, clerical dan medical.
\end{abstract}

Kata kunci : minat karir

\section{PENDAHULUAN}

Sekolah sebagai lembaga pendidikan, tempat untuk menimba ilmu, tempat melatih keterampilan, tempat untuk bersosialisasi serta tempat untuk mengembangkan bakat dan minat. Ternyata tuntutan masyarakat terhadap sekolah tidak hanya terbatas pada hal tersebut, perkembangan industri sekarang ini yang kian pesat ternyata membuat perusahaan-perusahaan melirik sekolah sebagai salah satu penyedia tenaga kerjanya walaupun bukan sebagai yayasan atau lembaga penyedia tenaga kerja, namun lebih sebagai lembaga yang menyiapkan kemampuan atau potensi untuk mampu bekerja. Bahkan ada juga lembaga pendidikan yang menjadi 
penghubung atau fasilitator antara pencari kerja dan pemberi kerja.

Permasalahan yang banyak dihadapi oleh pengusaha adalah kesulitan mencari tenaga kerja untuk perusahaannya. Padahal realitas yang ada dimasyarakat, jumlah tenaga kerja yang tersedia banyak sekali dan masih belum mendapatkan pekerjaan, namun mengapa perusahaanperusahaan masih merasa kesulitan untuk memperoleh tenaga kerja. Jawabannya adalah karena kualitas sumber daya manusia yang masih kurang memenuhi kualifikasi perusahaan.

Sekolah atau guru pada khususnya sebagai pendidik merupakan salah satu komponen penting dalam proses belajar mengajar di sekolah. Dipundaknya terdapat tanggung jawab dan harapan besar orang tua dalam upaya mengantarkan peserta didik kearah tujuan pendidikan serta harapan masyarakat. Tidak dapat dipungkiri, bahwa ujung dari proses pendidikan atau proses belajar mengajar di sekolah adalah mendapatkan pekerjaan yang layak dikemudian hari. Suatu hal yang wajar ketika para orang tua berusaha mencarikan sekolah yang bagus, yang berkualitas dengan harapan putra-putrinya mampu berkompetisi dengan anakanak yang lain. Puluhan juta bahkan ratusan juta dipersiapkan agar putraputrinya dapat menimba ilmu di lembaga yang dianggap berkualitas, yang menjadi harapannya.

Fakta di lapangan menunjukkan bahwa ada sekolah atau perguruan tinggi yang menjadi favorit, menjadi rebutan siswa atau orang tua. Ada fakultas atau program studi yang menjadi rebutan walaupun biaya yang harus dibayar dengan nilai ratusan juta. Berbagai alasan siswa dan orang tua berebut fakultas atau program studi studi tersebut, mulai dari melanjutkan atau penerus profesi orang tuanya, kemungkinan kemudahan peluang kerja ketika lulus, tidak banyak pesaing, bahkan pada persoalan nilai status sosial. Karena ada anggapan bahwa jika dapat diterima di fakultas tertentu, ia adalah anak yang pinter, anak yang cerdas, teman-temannya memiliki status sosial yang menengah keatas. Hal ini sering kali mengalahkan faktor minat dan kepribadian, yang sebenarnya juga sangat penting dalam proses belajar mengajar dan dalam dunia kerja. 
Sejalan dengan pergeseran makna pembelajaran dari pembelajaran yang berorientasi kepada guru (teacher oriented) ke pembelajaran yang berorientasi kepada peserta didik (student oriented), maka peran guru dalam proses pembelajaranpun mengalami pergeseran, salah satunya adalah penguatan peran guru sebagai motivator dan fasilitator. Dengan demikian, dalam hal ini selain peran guru sebagai pendidik dan pengajar juga peran guru dituntut sebagai motivator bagi siswanya. Karena dengan demikian, siswa tidak akan mengalami titik jenuh dalam belajar dan pada akhirnya minat dan motivasi siswa dalam belajar terus meningkat.

Keberhasilan belajar serta keberhasilan karir peserta didik dapat dipengaruhi juga oleh pemilihan dan penetapan peminatan belajar yang tepat. Peserta didik dalam proses pembelajaran akan melakukan penyesuaian-penyesuaian terhadap bidang keahlian atau bidang pelajaran yang ia tempuh. Ketika materi pelajaran yang ia terima sesuai dengan minat atau keinginannya tentunya akan lebih nyaman, tidak memerlukan penyesuaian yang berat. Hal ini memerlukan pendampingan agar jangan sampai mengalami kesulitan dan dapat berkembang secara cepat dan optimal sesuai dengan potensi yang dimilikinya.

Keadaan minat individu yang perlu diketahui karena ini merupakan suatu hal yang penting. Keadaan minat individu tersebut diketahui melalui pengukuran minat seperti yang dikemukakan oleh Sumadi Suryabra ta (2008), pengukuran minat merupakan hal yang penting karena terbukti minat mempunyai peran yang penting dalam hal berhasil tidaknya seseorang dalam berbagai bidang, terutama dalam studi dan kerja.

Arah peminatan peserta didik dapat dimulai saat peserta didik mengenal objek dan diberi kesempatan atau ada kesempatan untuk berbuat. Semenjak anak usia dini yang dikembangan melalui Pendidikan Anak Usia Dini, dilanjutkan ke pendidikan Sekolah Dasar, Sekolah Menengah Tingkat Pertama, Sekolah Menengah Tingkat Atas dan sampai di tingkat Perguruan Tinggi. Arah peminatan peserta didik sesuai dengan tingkat perkembangannya yang dapat berupa peminatan terhadap mata pelajaran, studi lanjut, keahlian, pekerjaan, jabatan, dan kehidupan keluarga. 
Harapan akhir dari pendidikan adalah peserta didik menjadi manusia yang berakhlak mulia, cerdas dan terampil, serta dapat mencapai kemandirian, kebahagiaan dan kesejahteraan.

Minat bukanlah hal yang dibawa sejak lahir, melainkan timbul sejalan dengan pengalaman individu. Minat bersifat pribadi dan berkembang dimulai sejak masa kanak-kanak (Crow \& Crow, 1979). Banyak hal yang mempengaruhi timbulnya minat baik yang berasal dari dalam diri individu itu sendiri maupun yang berasal dari lingkungan terutama lingkungan keluarga, lingkungan sekolah dan lingkungan masyarakat. Jika minat bukan faktor bawaaan, berarti minat diperoleh dari proses belajar dari lingkungan.

Sebagai manusia yang hidup di lingkungan masyarakat yang majemuk, apalagi pada era teknologi informasi yang berkembang sangat pesat seperti sekarang ini. Perkembangan teknologi yang sangat pesat ini telah membawa pada peradaban manusia yang global, pertukaran informasi mustahil untuk mampu dibendung. Kejadian detik ini yang ada di ujung barat juga akan diterima oleh orang-orang yang ada di ujung timur pada detik yang sama.
Kalau dulu orang yang bisa atau bercita-cita menjadi dokter adalah orang-orang kota, namun sekarang anak-anak yang tinggal di pegununganpun suda ada keinginan untuk menjadi dokter. Kalau dulu para guru banyak didatangkan dari kota, sekarang sudah banyak anakanak desa yang menjadi guru. Perubahan dan perkembangan ini tidak lepas dari lingkungan yang telah banyak memberikan informasi tentang berbagai profesi yang mungkin dapat diraih.

\section{METODE PENELITIAN}

\section{Populasi dan Subyek Penelitian}

Penelitian ini bertujuan untuk mengetahui perbedaan minat karir antara siswa sekolah menengah pertama (SMP) dengan siswa madrasah tsanawiyah (MTs). Pengambilan data dilakukan di SMP Unggulan Bina Insani Surabaya dan di MTs Negeri III Surabaya. Alasan pengambilan data dari dua sekolah ini karena adanya beberapa perbedaan dari kedua sekolah tersebut. Perbedaan utama adalah mengenai kurikulum atau mata pelajaran yang digunakan. Pelajaran yang bermuatan agama jauh lebih banyak ada di MTs dari pada di SMP. Selain itu, biasanya harapan dari orang siswa agar putra- 
putrinya dapat memahami pengetahuan agama, terutama agama Islam. Sampel penelitian adalah siswa kelas 7 yang masing-masing sekolah berjumlah 100 orang siswa.

\section{Teknik Pengumpulan Data}

Teknik pengambilan data dilakukan dengan menggunakan instrumen tes Rothwell Miller Interest Blank (RMIB), yaitu untuk mengetahui kecenderungan minat pekerjaan dari siswa. Aspek-aspek yang diungkap dari RMIB adalah

1. Outdoor : Pekerjaan yang dilakukan diluar, diudara terbuka, tidak berhubungan dengan hal-hal yang sifatnya rutin.

2. Mechanical : Pekerjaan yang berhubungan dengan mesin/alat mekanik.

3. Compulational : Pekerjaan yang berhubungan dengan angkaangka.

4. Scientific : Pekerjaan yang menyangkut aktifitas analisis, penyelidikan, penelitian, eksperimen kimia dan ilmu pengetahuan lainnya.

5. Personal Contact : Pekerjaan yang berhubungan dengan manusia, diskusi, membujuk, bergaul dengan orang lain, pada dasarnya adalah suatu pekerjaan yang membutuhkan kontak dengan orang lain.

6. Aesthetic : Pekerjaan yang berhubungan dengan hal seni dan menciptakan sesuatu.

7. Literary : Pekerjaan yang berhubungan dengan buku, membaca dan mengarang.

8. Musical : Memainkan musik, apresiasi, dan hal-hal lain yang berkaitan dengan musik.

9. Social Service : Pekerjaan yang berhubungan dengan pelayanan terhadap kepentingan masyarakat, kesejahteraan umum, membimbing, menasehati dan memahami.

10. Clerical : Pekerjaan yang menuntut ketelitian dan kerapian

11. Practical : Pekejaan yang memerlukan keterampilan, praktek, atau karya tangan.

12. Medical : Pekerjaan yang berhubungan dengan pengobatan, perawatan penyakit, penyembuhan dan hal yang dengan medis dan biologis.

\section{Teknik Analisis Data}

Analisis data penelitian dilakukan dengan menggunakan analisis statistik, yaitu t-tes. 
Pengolahan datanya dilakukan dengan komputer program SPSS-21.

\section{Hasil Penelitian}

Hasil analisis data yang dilakukan menunjukkan bahwa dari 12 aspek minat karir yang diungkap tes RMIB, hanya ada 3 aspek minat karir yang menunjukkan adanya perbedaan yang signifikan antara minat karir siswa SMP dengan minat karir siswa MTs, yaitu aspek scientific, personal contact dan practical. Sedangkan 9 aspek lainnya menunjukkan tidak ada perbedaan minat karir antara siswa SMP dengan siswa MTs. Aspek-aspek minat karir yang tidak berbeda adalah outdoor, mechanical, compulational, aesthetic, literary, musical, social service, clerical dan medical. Untuk lebih jelasnya dapat dilihat pada tabel berikut :

\begin{tabular}{|l|r|r|}
\hline \multicolumn{1}{|c|}{ Minat Karir } & \multicolumn{1}{c|}{ t } & Sig. \\
\hline Outdoor & -1.180 & .240 \\
\hline Mechanical & 1.095 & .275 \\
\hline Compulational & .589 & .557 \\
\hline Scientific & -3.914 & .000 \\
\hline Personal Contact & 3.921 & .000 \\
\hline Aesthetic & -1.889 & .060 \\
\hline Literary & -.296 & .768 \\
\hline Musical & .010 & .992 \\
\hline
\end{tabular}

\begin{tabular}{|l|r|r|}
\hline Social Service & .259 & .796 \\
\hline Clerical & 1.046 & .297 \\
\hline Practical & 2.166 & .032 \\
\hline Medical & -.267 & .790 \\
\hline
\end{tabular}

\begin{tabular}{|l|c|c|}
\hline \multirow{2}{*}{\multicolumn{1}{|c|}{ Minat Karir }} & \multicolumn{2}{c|}{ Mean } \\
\cline { 2 - 3 } Outdoor & SMP & MTs \\
\hline Mechanical & 53.48 & 55.66 \\
\hline Compulational & 46.61 & 44.82 \\
\hline Scientific & 64.39 & 55.46 \\
\hline Personal Contact & 50.64 & 72.62 \\
\hline Aesthetic & 62.77 & 65.4 \\
\hline Literary & 64.47 & 64.93 \\
\hline Musical & 59.58 & 59.56 \\
\hline Social Service & 70.2 & 69.76 \\
\hline Clerical & 69.03 & 67.41 \\
\hline Practical & 37.87 & 33.73 \\
\hline Medical & 66.59 & 67.17 \\
\hline
\end{tabular}

\section{PEMBAHASAN}

Aspek scientific merupakan minat terhadap pekerjaan yang menyangkut aktifitas analisis, penyelidikan, penelitian, Eksperimen kimia dan ilmu pengetahuan lainnya. Orang-orang yang suka pada bidang ilmiah ini akan memiliki pemikiran yang orisinil dan motivasi yang kuat untuk menerapkan ide-ide mereka hingga mencapai tujuan. Cepat 
melihat pola dalam peristiwa yang terjadi disekitar mereka, dan mampu menyusun perspektif jangka panjang yang jelas. Bila hendak melakukan sesuatu, ia akan mengorganisir lalu segera melaksanakannya. Sering kali bersifat skeptis namun mandiri, memiliki standar kompetensi dan kinerja yang tinggi untuk diri mereka sendiri maupun orang lain.

Hasil analisis data diketahui bahwa rata-rata minat scientific lebih tinggi pada siswa MTs dari pada siswa SMP. Hal ini menunjukkan bahwa siswa MTs memiliki keinginan untuk melanjutkan sekolah sampai di perguruan tinggi. Daya saing calon siswa MTs memang cukup tinggi, hal ini dibuktikan dengan banyaknya peminat yang mendaftar. Dukungan dari guru-guru juga cukup tinggi agar siswanya dapat melanjutkan ke jenjang perguruan tinggi. Adanya lingkungan yang demikian membuat para siswanya termotivasi untuk dapat melanjutkan sekolahnya ke perguruan tinggi.

Aspek personal contact merupakan minat terhadap pekerjaan yang berhubungan dengan manusia, diskusi, membujuk, bergaul dengan orang lain, pada dasarnya adalah suatu pekerjaan yang membutuhkan kontak dengan orang lain. Hasil analisis data diketahui bahwa rata-rata minat personal contact lebih tinggi pada siswa SMP. Interaksi yang terjadi sehari-hari di SMP ini memang sangat terbatas, jumlah penerimaan siswanya hanya sekitar 120 sampai 150 siswa dalam setiap tahunnya. Keterbatasan jumlah siswa ini membuat para siswanya cukup intesif dan cukup akrab dalam berinteraksi dengan teman-temannya.

Aspek practical merupakan minat terhadap pekerjaan yang memerlukan keterampilan, praktek, karya atau keterampilan tangan. Hasil analisis data diketahui bahwa rata-rata minat practical lebih tinggi pada siswa SMP. Aspek ini dapat dipandang kebalikan dari aspek scientific yang lebih menekankan pada potensi intelektualnya, sedangkan pada aspek praktical lebih banyak membutuhkan tenaga dan otot. Lingkungan sosial ekonomi keluarganya juga tergolong pada masyarakat menengah kebawah. Keinginan orang tua untuk menyekolahkan anaknya ke perguruan tinggi masih relatif rendah. Harapan para orang tua cenderung agar anaknya setelah lulus SMP melanjutkan ke SMK, dengan 
harapan lulus SMK bisa cepat bekerja.
Gerungan, Dipl. 2002. Psikologi Sosial. Bandung : Rafika Aditama

Dillard, 1985. Life Long Career Planning. Ohio : A Bell \& Howell Co

Sharf, R.S. (1992). Applying Career

Development Theory to Counseling. California: Brooks/ Cole Publishing Company.

Bimo Walgito. 2004. Pengantar Psikologi Umum. Yogyakarta

Sardiman,2007. Interaksi dan Motivasi Belajar Mengajar. Jakarta: PT. Grasindo Persada

Suparno, Paul. Teori Perkembangan Kognitif Jean Piaget. Yogyakarta: Kanisius

Slameto. 2003 . Belajar dan faktor faktor yang mempengaruhinya. Jakarta: Rineka cipta.

Winkel, W.S. (2005). Psikologi Pengajaran. Jakarta: PT. Gramedia Pustaka Utama

Hurlock, E.B, (1990) Psikologi Perkembangan Edisi ke-5, Jakarta: Erlangga

Natawijaya, Rahman.. Psikologi Pendidikan. Jakarta : Rineka Cipta, 2004

Djaali, 2007. Psikologi Pendidikan, Jakarta: PT Bumi Aksara. 
